\title{
When Does My Future Begin? Student Debt and Intragenerational Mobility
}

\author{
William Elliott ${ }^{1}$, Emily Rauscher ${ }^{2}$ \\ ${ }^{1}$ School of Social Work, University of Michigan, Ann Arbor, USA \\ ${ }^{2}$ Sociology Department, University of Kansas, Lawrence, USA \\ Email:willelli@umich.edu
}

How to cite this paper: Elliott, W., \& Rauscher, E. (2018). When Does My Future Begin? Student Debt and Intragenerational Mobility. Sociology Mind, 8, 175-201. https://doi.org/10.4236/sm.2018.82015

Received: March 3, 2018

Accepted: April 27, 2018

Published: April 30, 2018

Copyright (c) 2018 by authors and Scientific Research Publishing Inc. This work is licensed under the Creative Commons Attribution International License (CC BY 4.0).

http://creativecommons.org/licenses/by/4.0/

\begin{abstract}
Higher education financing policy largely assumes that college graduates enjoy equal opportunities for economic mobility regardless of how they finance their degrees. To examine this contention, this study uses data from the $\mathrm{Na}$ tional Longitudinal Survey of Youth 1979 to compare the time it takes to move up the economic ladder for young adult college graduates who acquired student debt and those who did not. Findings reveal that those who acquired student debt take longer to reach the midpoint of the net worth distribution than those who did not acquire student debt. In fact, even after controlling for key demographic differences, acquiring $\$ 10,000$ in student loans-only one-third of the average student debt load-is associated with an $18 \%$ decrease in the rate of achieving median net worth. Additionally, student debt may be associated with a slower rate of reaching median income; here, an additional $\$ 10,000$ in student loans is associated with a $9 \%$ decrease in the rate of achieving median income, although graphical evidence suggests these differences do not emerge until about age 35 . These findings reveal inequities in current education financing policy.
\end{abstract}

\section{Keywords}

Student Loans, Return on Degree, Wealth Inequality, Economic Mobility

\section{Introduction}

The American Dream holds that this country is a meritocracy where effort and ability should be the primary determinants of economic success. Americans' understanding of "effort and ability" features educational attainment-particularly higher education-prominently. Therefore, while European nations have relied on the "direct redistributive role of the welfare state to re- 
concile citizenship and markets", the United States has chosen to use education as a lever for ensuring equitable outcomes (Carnevale \& Strohl, 2010: p. 83). In 1976, in talking about the function of education in the American welfare system, Janowitz (1976) wrote:

Perhaps the most significant difference between the institutional bases of the welfare state in Great Britain and the United States was the emphasis placed on public education-especially for lower income groups-in the United States. Massive support for the expansion of public education, including higher education, in the United States must be seen as a central component of the American notion of welfare-the idea that through public education both personal betterment and national social and economic development would take place. (pp. 34-35)

A key early obstacle to making higher education a tool for creating equity was accessibility. The ability to pay for college was seen as a crucial barrier to education's ability to act as an equalizer in society. Federal financial aid emerged as a response to the affordability challenge. As such, "equity" became synonymous with "access", and bridging the immediate affordability gap was the primary-if not the sole-function of financial aid policy. In part as a compromise attempt to increase access while limiting federal spending (Elliott \& Lewis, 2017), since the late 1970s, the federal government has increasingly attempted to solve the access problem by making student loans more readily available to students. Regulatory concessions sought to encourage private lenders to provide student loans (Elliott \& Lewis, 2017), while the federal government developed and expanded programs such as federal Parent PLUS Loans and Stafford subsidized and unsubsidized loan programs. In 2000, student loans paid for 38\% of net tuition, fees, room, and board; by 2013 they covered 50\% of these costs (Greenstone, Looney, Patashnik, \& Yu, 2013). Current student debt levels exceed \$1 trillion dollars; in 2007, total student debt surpassed credit card debt in America (Hartman, 2013). In 2013, the average student left college with about $\$ 29,400$ of student loan debt (Miller, 2014).

Accessibility only opens the door to higher education. We posit that how students pay for college is also an important factor in whether or not college can promote equality. From this perspective, there is a difference between paying for college with and without loans. However, largely conflating access and equity, financial aid research has paid little attention to whether or not the different ways students pay for college allow higher education to reduce inequality. Most of the research on the return of a college degree is designed to answer the question, "Is a young adult who attends college better off than if he or she did not attend college at all?" Researchers adopting the "better off" perspective predominant in the higher education literature suggest that the correct comparison to make is between college goers and non-college goers (e.g., Dynarski, 2016). This is an important question for understanding the continuing contribution of higher educational attainment in determining young people's outcomes. However, it is not sufficient for understanding higher education's equalizing capacity. 
To examine the equalizing potential of higher education in the current financing context, researchers must also ask, "Do college goers who acquire student debt achieve outcomes similar to college goers who do not acquire student loans?" If educational access alone allows individuals to achieve their potential, the way in which students pay should not matter for their economic outcomes.

Magnifying the need to examine inequity in outcomes from financing college with student loans is the fact that people do not rely equally on student loans to pay for college. Huelsman (2015) reported that $84 \%$ of bachelor's degree recipients at public colleges who receive Pell Grants take out student loans, compared to $46 \%$ of those who never received Pell assistance. Nor is income the only dimension of inequity. Grinstein-Weiss, Perantie, Taylor, Guo, \& Raghavan (2016) found that the odds of a Black low- and moderate-income (LMI) student having outstanding student debt was twice as high as a White LMI student, and Black LMI students incurred about $\$ 7721$ more student debt than their White counterparts. Furthermore, research has revealed that low-income and minority students receive less of a return on a college degree than their counterparts. Hershbein (2016) found that young adults with a college degree who come from families with an income below $185 \%$ of the federal poverty level earn $91 \%$ more over their careers than young adults similarly situated with only a high school degree, while college graduates from families with incomes above $185 \%$ of the FPL earned $162 \%$ more during their working years than their high school graduate peers. What these findings suggest is that college pays off more for those who grow up in families with higher incomes than for those economically disadvantaged. Similarly with regard to race, researchers at the Federal Reserve Bank of St. Louis found that Hispanic ( $\$ 68,379$ income $\$ 49,606$ net worth) and Black American students ( $\$ 52,147$ income/ $\$ 32,780$ net worth) receive less benefit from having obtained a degree than their White $(\$ 94,351$ income $\$ 359,928$ net worth) and Asian (\$92,931 income/\$250,637 net worth) counterparts with regard to their 2013 annual median income and median net worth, respectively (Emmons \& Noeth, 2015). They also found evidence that a college degree protects college graduates' income and wealth unequally. Median wealth declined between 2007 and 2013 by about $16 \%$ among White college graduate families, versus a decline of about $33 \%$ among White families without a college degree and $72 \%$ among Hispanic college graduate families versus a decline of $41 \%$ among Hispanic families without a college degree. Among Blacks, the declines were $60 \%$ versus $37 \%$ (Emmons \& Noeth, 2015). While these studies do not test whether or not financing college with student loans might help explain some of the difference in the return on a degree described here, there is a growing body of research which suggests this might be the case.

We review research on unequal returns in homeownership, retirement savings, and net worth in the following section. Based on that review, we identify our research questions and the methods we use to address them. Specifically, we use survival analysis of data from the National Longitudinal Survey of Youth 1979. Based on those analyses, we find that those who acquired student debt take 
longer to reach the midpoint of the net worth or income distributions than those who did not acquire student debt. Finally, we discuss these findings in light of existing research and offer potential policy implications.

\section{Review of Research}

\subsection{Delayed Returns}

Research indicates that students who graduate with average student loan debt may be forced to delay purchasing wealth-building items such as a home during the early part of their working lives (Brown \& Caldwell, 2013; Dynarski, 2016; Stone, Van Horn, \& Zukin, 2012; Houle \& Berger, 2014; Shand, 2007). In some scholarly discussions, these delays have been characterized as minor. For example, Rose (2014) stated, "A sizable number of people are certainly inconvenienced for their first 10 years after graduation and face a long period of repayments, but a relatively small percentage confront default" (p. 30, emphasis added). This analysis defines "problematic" student debt by the rather extreme outcome of loan default, while appearing to accept a system that delivers a delayed return on degree for student borrowers. Indeed, it appears that students with debt wait even longer than 10 years to receive an equal return on their degree. The average time that it takes to repay student loans grew from about seven years in 1992 to a little more than 13 years in 2010 (Akers \& Chingos, 2014), fueled in part by growing use of Income-Based Repayment plans (Akers \& Chingos, 2014), which extend normal repayment plans from 10 years to up to 25 years to help overburdened students cope with the cash strain presented by their debt burdens. However, these delays may help account for the wealth inequality seen later in life between college graduates with and without outstanding student debt. Below, we review research on the correlational relationship between student debt and asset accumulation.

\subsection{Homeownership}

Brown \& Caldwell (2013) showed that as credit scores of student borrowers declined and student debt per borrower increased, homeownership rates of 30 -year-old student loan borrowers decreased by more than $5 \%$, compared with homeownership rates of 30-year-old non-borrowers. According to Brown \& Caldwell (2013), this is a fairly substantial drop, particularly given the overall homeownership rate for 30-year-olds of below 24\%. The Federal Reserve Bank of New York speculates that the drop in homeownership rates post-Great Recession is due in part to tighter underwriting standards and higher mortgage delinquency rates (Brown et al., 2014). Even when they purchase homes, student debtors may face terms that compromise their asset accumulation potential. Mishory \& O'Sullivan (2012) found that the average single student debtor would have to pay close to half of his or her monthly income toward student loans and mortgage payments. As a result, the debtor would not qualify for a Federal Housing Administration loan or many affordable private loans (Mishory \& 
O'Sullivan, 2012). Instead, higher interest rates may make it harder to earn equity in the house and price indebted households out of the most desirable markets.

However, the Federal Reserve Bank of New York's research on the relationship between student debt and homeownership has come under some attack. Specifically, Dynarski (2016) critiqued these findings because the data do not contain information on college attendance. She contended that the correct comparison is between the homeownership rates of college goers and non-college goers. Making this comparison, Dynarski (2016) found that before the recession, $35 \%$ of college goers owned a home, compared to $23 \%$ of non-college goers; after the recession, homeownership rates dropped to $26 \%$ among college goers compared to $17 \%$ among non-college goers. However, when Dynarski (2016) compared college goers who had student debt to college goers who did not, she found statistically significant differences in homeownership rates persisted until the college goers reached the age range of 33 to 35. Such delays in homeownership may reduce student borrowers' ability to accumulate equity as homeowners, thus compromising their overall net worth.

Similarly, other researchers have found that homeownership is delayed among those with debt compared to those without. Stone et al. (2012) found that $40 \%$ of students graduating from a four-year college with outstanding student loan debt delay a major purchase, including a home. Cooper \& Wang (2014) found that student loan debt among individuals who attended college during the 1990s lowered the chances of buying a home by age 30. Similarly, Houle \& Berger (2014) found that student debt was associated with a delay in home purchase among college graduates with outstanding student debt compared with those without outstanding student debt. Although Houle and Berger's findings are significant but not very strong in the aggregate, they found evidence that these effects are much stronger among Black graduates with outstanding student debt (2014). Purchasing a home later in life and/or purchasing at a higher interest rate may be associated with having less home equity as well. Hiltonsmith (2013) found that households with four-year college graduates and outstanding student debt had $\$ 70,000$ less in home equity than similarly-situated households without outstanding student debt.

Shand (2007) also found evidence that student debt had a negative effect on homeownership rates when comparing four-year college graduates with and without debt. However, she found little evidence that this wealth loss is the result of credit constraints; instead, households with outstanding student debt may be averse to obtaining a mortgage for a home. In this manner, student loans may introduce additional levers of inequality into students' post-college lives, artificially constraining home purchase and preventing the development of a powerful asset base (Shapiro, Meschede, \& Osoro, 2013). The reason for these differences between graduates with and without student loans may change over time, in relation to changes in the credit markets and macroeconomic conditions in which these financial decisions are made. For example, Brown \& Caldwell (2013) 
found that credit scores of student loan borrowers and non-borrowers were essentially the same in 2003, but by 2012 borrowers had lower scores. Longitudinal research can improve our understanding of the relationship between student loans and wealth accumulation, while accounting for cohort differences in macroeconomic context.

\subsection{Retirement Savings}

A few studies have examined the relationship between student debt and retirement savings. In a national survey, American Student Assistance (2013) found that among young adults with outstanding student debt, $73 \%$ reported putting off saving for retirement or other investments. Using regression analyses, Elliott, Grinstein-Weiss, \& Nam (2013) found that families with outstanding student debt had 52\% less retirement savings than families with no outstanding student debt. Hiltonsmith's (2013) results indicated that dual-headed households with a college graduate and median student debt $(\$ 53,000)$ had about $\$ 134,000$ less in retirement savings than dual-headed households with a college graduate and no student debt. Similarly, in a simulation, Egoian (2013) found that four-year college graduates with median debt of $\$ 23,300$ had $\$ 115,096$ less in retirement savings than a four-year college graduate with no student loans by the time they reach age 73 .

\subsection{Net Worth}

Several studies have tested whether there is a relationship between having outstanding student debt and family net worth. For example, Elliott \& Nam (2013) found that families with college debt had $63 \%$ less net worth than those without outstanding student debt. Similarly, over the life course, Hiltonsmith (2013) found that an average student debt load $(\$ 53,000)$ for a dual-headed household with bachelor's degrees from four-year universities led to a wealth loss of nearly $\$ 208,000$. Fry (2014) found that a household headed by a college graduate without outstanding student debt has seven times $(\$ 64,700)$ the typical net worth of a household headed by a college graduate who has outstanding student debt $(\$ 8,700)$. Cooper \& Wang (2014) found evidence that student debt has a negative correlation with wealth for households with at least some college experience and a head or spouse 40 years old or younger. Furthermore, they found that the negative relationship between student loan debt and net worth was more noticeable among homeowners than renters, suggesting the delay in homeownership initiation reduces net worth for borrowers.

Research reviewed in this section suggests that outcomes diverge for different types of college goers and that student loan usage may be one of the critical factors driving this inequity. This study is designed to better understand these relationships.

\subsection{Research Questions}

In this study we build on previous research by examining the time it takes young 
adults with and without student debt to move up the economic ladder to the midpoint of the distribution. The analysis seeks to answer two questions:

1) What is the relationship between student debt and the time it takes young adults who graduate from college to reach median income and net worth (the midpoint of the income and asset distributions)?

2) Does this relationship differ by gender or race?

The statistical analysis is designed to estimate differences between young adult college graduates with and without student debt, controlling for extraneous factors. Based on the literature review above, we hypothesize that college graduates with student debt will take longer to reach median income and net worth. Furthermore, we hypothesize that the relationship will be stronger among Black than White graduates, but that the relationship will be similar by gender.

\section{Methods}

\subsection{Data}

We use student loan, net worth, and income data from the National Longitudinal Survey of Youth 1979 (NLSY97). The National Longitudinal Surveys (NLS) are designed to gather information at multiple points in time on the labor market activities and other significant life events of several groups of men and women. These longitudinal datasets follow the same individuals over a long period, interviewing them once every calendar year. The 1979 cohort followed 12,686 young people and recorded their significant life events in areas such as education, family, and employment. A number of these individuals are still participating in this ongoing survey. It would be useful to examine both the NLSY79 and 97 cohorts, however, unfortunately, in the 1997 cohort, net worth was only collected at certain ages (e.g., ages 25 and 30) or according to certain independence rules for initial net worth. In the NLSY97 cohort, therefore, wealth is collected at infrequent intervals depending on age. Estimates of the time it takes to reach median wealth in NLSY97 data would likely depend strongly on age simply because we do not observe wealth at all ages. Given the limitations of the 1997 study, we use data from the NLSY79 only.

\subsection{Sample}

We limit our analyses to young adults with a four-year college degree who are at least age 22, which is in the typical age range of college graduation. We include young adults who have a postgraduate degree because many college graduates do earn a graduate degree and because this could be influenced by student loans acquired as an undergraduate. The longitudinal data include repeated measures over a 32-year span with the baseline year being the year that each subject reached the age of 22. Most young adults are not observed for the full 32 years, but we include all of the data available.

\subsection{Measures}

Our primary measures of interest include household net worth, household in- 
come, and amount of student loans ever acquired. Amount of student loans includes the total amount of education loans received from the first, second, and (in most years) third most recent colleges attended. In each year, the survey asked respondents if they attended college since the date of the last interview. If so, it collected information on the total amount of education loans acquired in 1984-1986, 1988-1990, 1992-1994, and then biennially. We adjust for inflation to 2010 dollars and calculate a cumulative total of student loans ever acquired for each individual. Based on this information, we create an indicator for whether the respondent received any student loans.

Net worth includes all assets minus outstanding debt. NLSY79 collected information on multiple types of assets and debt in 1985-1990, 1992-1994, 1996, 1998, 2000, 2004, and 2008. We measure net worth in these years. NLSY79 did not collect asset data in 1991, 2002, 2006, or 2010. Net worth is therefore missing in those years for all respondents. In the survey, respondents estimate the approximate value of their home, savings, business, and automobile, as well as any mortgage or other debt. The survey administrators top code net worth and income measures to prevent identification; the values of those who fall above a certain threshold (the top $2 \%$ beginning in 1996) are replaced with the average of those above the threshold. Net worth is adjusted for inflation to 2010 dollars using the Bureau of Labor Statistics inflation calculator. In 2004 and 2008, NLSY79 collected information about outstanding student loan debt of the respondent and his/her partner. However, because this information is available in only two years, our main analyses include total net worth unadjusted for student loans. Sensitivity analyses using an alternative measure of net worth that adds the total amount of outstanding student loans to 2004 and 2008 net worth measures yield similar results.

Household income is measured in two ways-gross income and wage income. Gross income includes total household income from all sources recorded by the NLSY79. Wage income includes income from wages and salary of the individual and his/her partner. Income is available each year from 1979 to 1994 and every two years after 1994. In each year it is collected, the income value represents income from the previous year. Both income measures are adjusted for inflation based on the income year the value represents. For example, income in 1979 represents 1978 income and is adjusted for inflation to 2010 dollars based on the 1978 inflation factor from the Bureau of Labor Statistics inflation calculator.

Many students never acquire student loans and among those who do there is a great deal of variation. A small number of students take on very high student debts, which would skew the results. Therefore, we use the inverse hyperbolic sine (IHS) transformation to address skewness and prevent the exclusion of those with negative net worth values.

Using household income and net worth values, we calculate indicators for whether the individual's household net worth or income exceeds the median net worth or income in the U.S. in a given year. Median household income and net worth data are obtained from external sources to provide a more accurate meas- 
ure of absolute mobility. Median income for each year from 1979-2010 is obtained from the Census. Median wealth for years 1979-2008 is obtained from Saez \& Zucman (2016). NLSY79 did not collect net worth in 2010, so we do not have an indicator for whether an individual reached median net worth in 2010.

A number of covariates are used in the analysis. In our preferred analyses, we include only race and gender. Other measures include: level of higher education; occupational category; marital status; welfare use; geographic location; and baseline net worth or income at the first observation. These variables are coded as follows. Level of higher education consists of two indicators: four-year degree or a postgraduate college degree. We create indicators for four broad occupational categories: professional or management occupations; sales or administration occupations; operations, service, farm, or armed forces occupations; and no occupation. Marital status includes three indicators: single; married; and separated, divorced, or widowed. Welfare use is an indicator for receipt of any welfare support. Geographic location includes indicators for each region of the U.S. (North East, North Central, West, and South) as well as an indicator for urban residence. Baseline net worth and income is the initial net worth or income value at age 22, or the first observed value if net worth or income is missing at age 22 . We use the previously-observed value to replace missing values of family size, marital status, occupational category, and geography when possible, but results are similar without replacing these values.

\subsection{Analysis Plan}

We first graphically compare the mobility patterns of those with and without any student loans using Kaplan-Meier estimates of the survival function. The Kaplan-Meier estimator provides an estimate of the probability of survival past a given time, $t$. In this case, "survival" represents those who have not achieved median income or net worth at a given time; "failure" indicates achieving median income or net worth. Throughout our analyses, we are estimating the time it takes to move up the economic ladder to the midpoint of the distribution. Since Kaplan-Meier is a non-parametric estimator, we are not required to make any parametric assumptions. The Kaplan-Meier estimates provide a visual method for inspecting the survivor functions of different groups, in this case those who differed in the acquisition of student loan debt.

We then use survival analysis to estimate the time it takes an individual to reach median net worth or income from age 22 and whether that time varies by student loan debt. Measuring mobility to the median of the distribution allows us to measure mobility to the top half of the income and wealth distributions in the U.S., which may provide a sense of having "made it", as understood in American society. It also indicates movement out of the bottom, which may be more difficult for some groups of graduates. Measuring mobility in this way provides a consistent measure over time that also accounts for changes in the distribution. We will also investigate whether this relationship varies by gender 
or race.

Survival analysis does not assume normally distributed error terms and incorporates the rich longitudinal information available in the NLSY79. Our primary analyses use a semi-parametric estimation technique, specifically the Cox proportional hazards model, which does not parameterize the baseline hazard function but assumes that the covariates multiplicatively shift the baseline function. While parametric survival analysis models require specifying a distribution of survival time, the Cox proportional hazards model avoids the issue of time dependence and only assumes proportional hazard rates over time. That is, it assumes that cases at different values of an $\mathrm{X}$ variable have the same ratio or relative difference in risk over time. This assumption is testable and, in instances when it does not hold, time-varying covariates are added to address any variation in their importance over time.

More technically, the proportional hazards model portrays the ratio of the hazard rate to a baseline hazard rate as an exponential function, as in the following equation:

$$
\ln (h(t))=\ln \left(h_{o}(t)\right)+b_{1} x_{1}+b_{2} x_{2}+\cdots+b_{p} x_{p}
$$

Models predict the log of the hazard rate, with the log of the baseline hazard rate entered as a constant. Since the hazard rate is expressed as a function of the baseline hazard rate and not time, time dependence does not have to be modeled. The proportional hazard rate is calculated at each year for those in the risk set, which reduces the importance of minor measurement inconsistencies across years. The risk set includes households that have not reached median income or wealth as of the preceding survey wave.

Survival analysis requires some transformations to the data to enable the calculation of the probabilities of failure. We conduct the analysis using Stata statistical software which has a well-developed set of commands for data transformation, data analysis, and reporting. The baseline observation is the year in which the respondent turns 22 . The hazard rate for individuals reaching the median net worth or income threshold is measured annually through a survival analysis approach until the final endpoint in 2010 (2008 for net worth). The data are right-censored and individuals are removed from the risk pool once they have achieved median net worth or income. We use the default Breslow method for ties in the timing of reaching median net worth or income.

We estimate three Cox models using the full sample of college graduates. The first includes only student loans. The second controls for gender and race, to address the possibility that both student loan amounts and net worth or income could differ by gender and race. The third includes several additional controls, including level of higher education, occupational category, marital status, welfare use, geographic location, and baseline net worth or income. The third model includes measures that could depend on outstanding student loans, which can make it difficult to interpret the results. For example, student loans could en- 
courage individuals to prioritize income over other factors in choosing an occupation or encourage them to live in a region with higher income potential. Loans could also encourage some college graduates to acquire postgraduate education, while discouraging others. Due to these potential heterogeneous responses, our preferred estimates include only gender and race, along with student loan value. However, we include the third model with multiple covariates to assess robustness.

Finally, we estimate whether the relationship between student loans and time to achieve median net worth or income differs by race or gender. We do this by including interaction terms and also by estimating separate models when limiting the samples to men, women, Black, Latino, and other race individuals.

\section{Results}

\subsection{Descriptive Results}

Table 1 summarizes the sample of young adults in the NLSY79, limited to those over age 21 with at least a four-year college degree. Of interest, average student debt in this study is $\$ 24,534.42$ (median $\$ 13,494$ ). Further, descriptive data indicate that college graduates with student loans have about $30 \%$ less net worth than college graduates without student loans. This is consistent with the possibility that graduates with student loans could take longer to reach median net worth. However, these descriptive statistics do not account for potentially important demographic and occupational characteristics, which could account for these differences.

Table 2 examines net worth and household income among participants age 40 and above. The descriptive data indicate that while college graduates with student loans earn more, they have less net worth. This is supported by the fact that while college graduates with student loans have higher wage income than college graduates without student loans, there is not a statistical difference in their total income (wages, income from assets, and income from transfers).

\subsection{Survival Analysis Results}

Figure 1 shows Kaplan-Meier estimates of the likelihood of remaining below median wealth for college graduates who acquired student loans and those who did not. The figure illustrates that those with student loans achieve median net worth more slowly than those without student loans. That is, the survival curve for four-year college degree holders with student loans falls less slowly than the curve for those who completed their education without acquiring student loans. In addition, those who acquired student loans are slightly less likely to achieve median wealth by age 52 than those who never took on student loans.

Figure 2 shows Kaplan-Meier estimates of the likelihood of remaining below median household income for college graduates who acquired student loans and those who did not. The curve for young adults with student loans falls slightly more quickly but is slightly higher around age 35 than the curve for those 
Table 1. Descriptive statistics.

\begin{tabular}{|c|c|c|c|c|c|}
\hline Variable & $M$ & $S D$ & $\begin{array}{l}\text { Any Student } \\
\text { Loan }\end{array}$ & $\begin{array}{l}\text { No Student } \\
\text { Loan }\end{array}$ & T-test \\
\hline Total Student Loans & $\$ 14,400.60$ & $\$ 27,737.26$ & $\$ 24,534.42$ & $\$ 0.00$ & . \\
\hline Any Loans & 0.59 & 0.49 & 1.00 & 0.00 & . \\
\hline Net Worth 1 & $\$ 232,965.80$ & $\$ 519,692.70$ & $\$ 199,045.90$ & $\$ 283,797.60$ & $* *$ \\
\hline High Net Worth 1 & 0.59 & 0.49 & 0.53 & 0.68 & $* *$ \\
\hline Baseline Net Worth 2 & $\$ 739,188.00$ & $\$ 981,457.10$ & $\$ 680,658.50$ & $\$ 822,543.50$ & $* *$ \\
\hline Household Gross Income 3 & $\$ 180,752.50$ & $\$ 258,383.20$ & $\$ 176,762.30$ & $\$ 186,464.00$ & $* *$ \\
\hline Household Wage Income & $\$ 87,450.30$ & $\$ 240,861.70$ & $\$ 87,491.19$ & $\$ 87,392.18$ & \\
\hline High Gross Income 3 & 0.75 & 0.43 & 0.75 & 0.76 & * \\
\hline High Wage Income & 0.57 & 0.50 & 0.56 & 0.58 & $* *$ \\
\hline Baseline Gross Income 3 & $\$ 125,605.10$ & $\$ 122,738.70$ & $\$ 116,522.00$ & $\$ 138,512.60$ & $* *$ \\
\hline Baseline Wage Income & $\$ 37,588.09$ & $\$ 43,000.25$ & $\$ 33,614.78$ & $\$ 43,234.34$ & $* *$ \\
\hline Age & 33.37 & 8.22 & 33.28 & 33.49 & ** \\
\hline Male & 0.45 & 0.50 & 0.46 & 0.44 & $* *$ \\
\hline Female & 0.55 & 0.50 & 0.54 & 0.56 & $* *$ \\
\hline Black & 0.20 & 0.40 & 0.22 & 0.18 & $* *$ \\
\hline Latino & 0.12 & 0.33 & 0.13 & 0.12 & $* *$ \\
\hline Other Race & 0.67 & 0.47 & 0.65 & 0.70 & $* *$ \\
\hline Four-Year Degree & 0.79 & 0.41 & 0.74 & 0.86 & $* *$ \\
\hline Postgraduate Degree & 0.21 & 0.41 & 0.26 & 0.14 & $* *$ \\
\hline Family Size 4 & 2.84 & 1.55 & 2.79 & 2.91 & $* *$ \\
\hline Single 5 & 0.35 & 0.48 & 0.38 & 0.32 & $* *$ \\
\hline Married 5 & 0.54 & 0.50 & 0.51 & 0.58 & $* *$ \\
\hline $\begin{array}{c}\text { Separated, Divorced, or } \\
\text { Widowed } 5\end{array}$ & 0.11 & 0.31 & 0.11 & 0.10 & ** \\
\hline Welfare Support & 0.03 & 0.17 & 0.03 & 0.03 & ** \\
\hline No Welfare Support & 0.97 & 0.17 & 0.97 & 0.97 & $* *$ \\
\hline Professional Occupation 6 & 0.23 & 0.42 & 0.25 & 0.21 & $* *$ \\
\hline Sales/Admin Occupation 6 & 0.07 & 0.25 & 0.07 & 0.07 & \\
\hline $\begin{array}{l}\text { Service, Operations, Farm, } \\
\text { Armed Forces } 6\end{array}$ & 0.06 & 0.24 & 0.05 & 0.07 & ** \\
\hline No Occupation 6 & 0.64 & 0.48 & 0.62 & 0.65 & $* *$ \\
\hline Urban 7 & 0.83 & 0.38 & 0.83 & 0.82 & \\
\hline Rural 7 & 0.17 & 0.38 & 0.17 & 0.18 & \\
\hline North East 8 & 0.20 & 0.40 & 0.20 & 0.19 & * \\
\hline North Central 8 & 0.24 & 0.43 & 0.26 & 0.21 & ** \\
\hline Table 1 (continued) West 8 & 0.18 & 0.39 & 0.18 & 0.19 & * \\
\hline South 8 & 0.38 & 0.48 & 0.36 & 0.41 & $* *$ \\
\hline
\end{tabular}




\section{Continued}

\begin{tabular}{llll}
\hline N & 61,664 & 36,194 & 25,470 \\
N 1 & 35,205 & 21,115 & 14,090 \\
N 2 & 61,547 & 36,158 & 25,389 \\
N 3 & 57,214 & 33,683 & 23,531 \\
N 4 & 54,723 & 32,556 & 22,167 \\
N 5 & 54,721 & 32,555 & 22,166 \\
N 6 & 54,646 & 32,514 & 22,132 \\
N 7 & 51,784 & 30,910 & 20,874 \\
N 8 & 53,951 & 32,186 & 21,765 \\
\hline
\end{tabular}

Note. NLSY79 data limited to those age 22 and over with at least a four-year college degree. We use the previously observed value to replace missing values of family size, marital status, occupational category, and geography when possible. T-test indicates statistical significance of difference in means between those with and without any student loans: ${ }^{* *} p<0.01 ;{ }^{*} p<0.05 ;+p<0.10$.

Table 2. Mean differences in net worth and household income among those age 40 and above.

\begin{tabular}{cccccc}
\hline Variable & \multirow{2}{*}{ All } & $\begin{array}{c}\text { Any Student } \\
\text { Loan }\end{array}$ & $\begin{array}{c}\text { No Student } \\
\text { Loan }\end{array}$ & Difference & T-Test \\
\hline Net Worth & $\$ 493,369.50$ & $\$ 446,091.40$ & $\$ 561,249.40$ & $\$ 115,158.00$ & $* *$ \\
Household Gross Income & $\$ 126,743.40$ & $\$ 127,019.50$ & $\$ 126,349.00$ & $-\$ 670.50$ & \\
Household Wage Income & $\$ 80,470.43$ & $\$ 83,298.30$ & $\$ 76,541.75$ & $-\$ 6,756.55$ & $* *$ \\
\hline
\end{tabular}

Note. NLSY79 data limited to those age 40 and over with at least a four-year college degree. T-test indicates statistical significance of difference in means between those with and without any student loans: ${ }^{* *} p<0.01$; ${ }^{*} p<0.05 ;+p<0.10$.

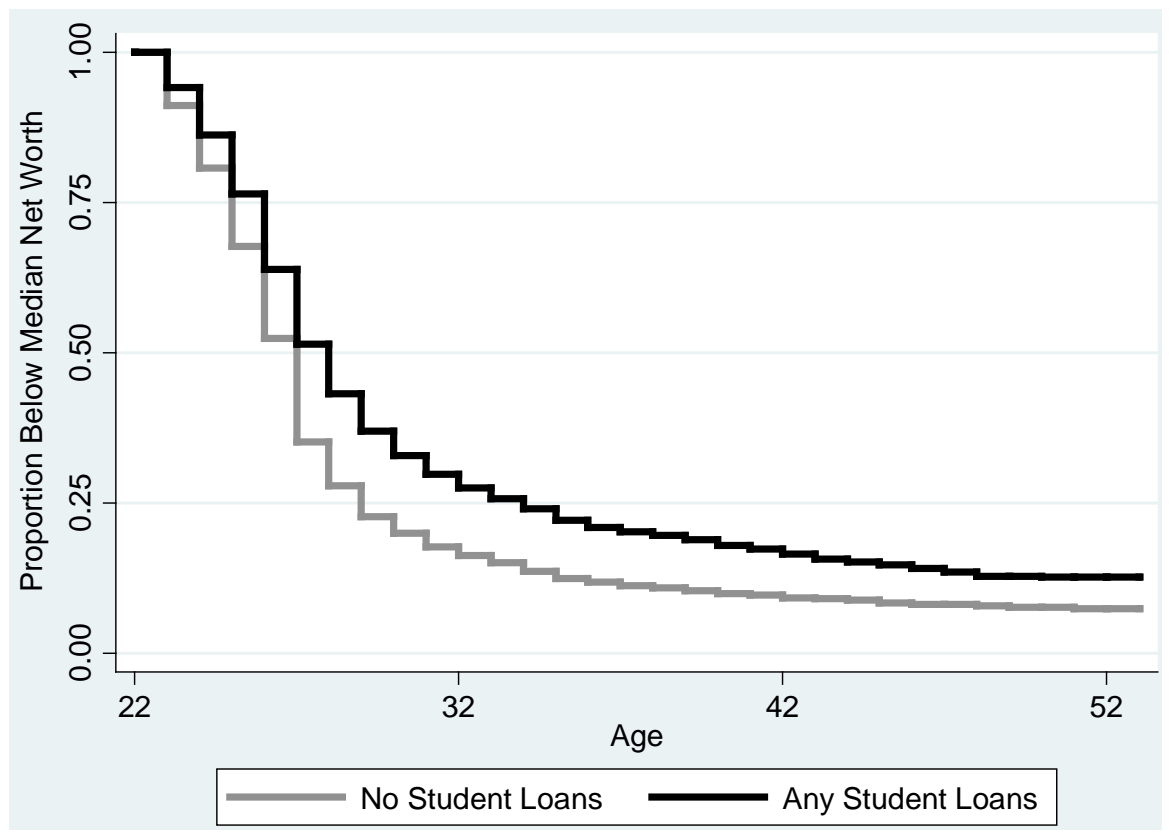

Figure 1. Kaplan-meier survival estimates of time to median net worth. 


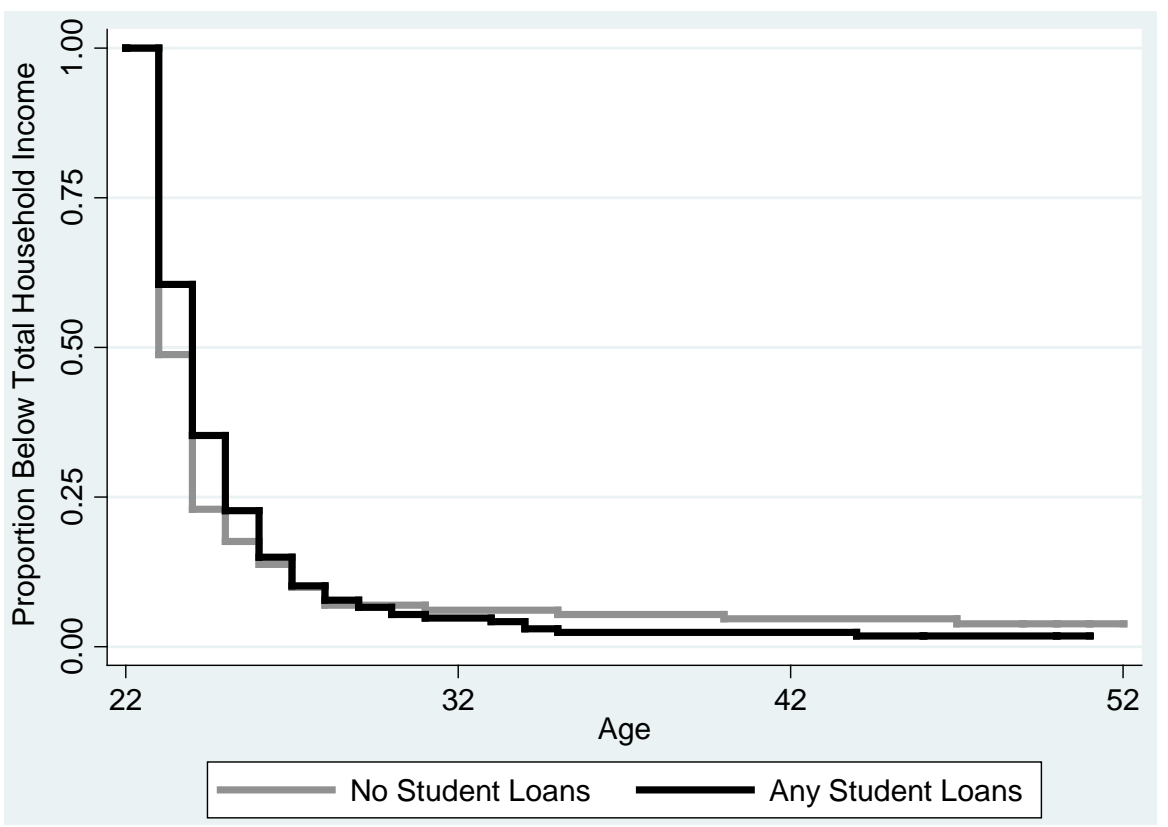

Figure 2. Kaplan-meier survival estimates of time to median total household income.

without. These differences, however, are small and may not be significant. The graph for wage income is similar to that for total household income and not shown.

Table 3 includes the mean and median amount of time required to reach median wealth or income among college graduates who did and did not acquire student loans. Time is measured in years and we begin our analyses from age 22, so median time to exit indicates the number of years after age 22 required for half the sample to reach median net worth or income. The sample sizes in Table 3 reflect that many young adults have already achieved median total household income by age 22 . The analyses are conducted on college graduates who have not already achieved the outcome measure. In other words, we limit each individual to one failure; once they have ever reached median wealth or income, they are removed from the risk set. The descriptive results in Table 3 suggest that young adults who acquire student loans reach median wealth more slowly than their counterparts who do not. However, the difference between those with and without student loans does not seem to exist for income.

In order to test differences statistically, we use the log rank test, which is an extension of the Mantel-Haenszel test. The test statistic is obtained by constructing contingency tables at each distinct failure time and then combining these results. The test compares the observed number of failures against the expected number of failures to establish equality under the null hypothesis of no difference in survival among the groups.

Table 4 shows that the log rank test of difference between those with and without student loans in the timing of reaching median net worth is significant. In other words, there is sufficient difference between the observed and expected number of failures for us to reject the null hypothesis of no difference between 
Table 3. Time to reach median net worth and income.

\begin{tabular}{cccccccc}
\hline Outcome Measure & $\begin{array}{c}\text { Median } \\
\text { Exit Time }\end{array}$ & $S E$ & 95\% CI & $\begin{array}{c}\text { Mean } \\
\text { Exit Time }\end{array}$ & $\begin{array}{c}\text { Incidence } \\
\text { Rate }\end{array}$ & $N$ \\
\hline No Student Loans & & & & & & & \\
\hline Median Net Worth & 5 & 0.09 & 4 & 5 & 6.95 & 0.13 & 1147 \\
Median Total Income & 1 &. & 1 & 2 & 3.27 & 0.29 & 131 \\
Median Wage Income & 3 & 0.09 & 2 & 3 & 5.2 & 0.18 & 774 \\
\hline Student Loans & & & & & & & \\
\hline Median Net Worth & 6 & 0.12 & 5 & 6 & 9.26 & 0.09 & 1714 \\
Median Total Income & 2 & 0.15 & 2 & 2 & 3.11 & 0.32 & 167 \\
Median Wage Income & 3 & 0.1 & 3 & 3 & 5.18 & 0.18 & 1283 \\
\hline
\end{tabular}

Note: NLSY79 data limited to those age 22 and over with at least a four-year college degree.

Table 4. Log rank tests for equality of survivor functions.

\begin{tabular}{|c|c|c|c|c|c|c|}
\hline & \multicolumn{6}{|c|}{ Outcome Measure } \\
\hline & \multicolumn{2}{|c|}{$\begin{array}{l}\text { Median Net } \\
\text { Worth }\end{array}$} & \multicolumn{2}{|c|}{$\begin{array}{c}\text { Median Total } \\
\text { Income }\end{array}$} & \multicolumn{2}{|c|}{$\begin{array}{l}\text { Median Wage } \\
\text { Income }\end{array}$} \\
\hline Variable & $x^{2}$ & & $x^{2}$ & & $x^{2}$ & \\
\hline Any Student Loans & 65.90 & $* *$ & 0.69 & & 1.08 & \\
\hline Male & 13.27 & $* *$ & 2.53 & & 0.57 & \\
\hline Black & 89.80 & $* *$ & 10.04 & $* *$ & 65.13 & $* *$ \\
\hline Latino & 0.36 & & 2.42 & & 5.80 & * \\
\hline Postgraduate Degree & 1.74 & & 0.22 & & 4.62 & * \\
\hline Single & 468.56 & $* *$ & 6.63 & * & 216.57 & $* *$ \\
\hline Married & 746.59 & $* *$ & 11.64 & $* *$ & 358.30 & $* *$ \\
\hline Separated, Divorced, or Widowed & 66.80 & $* *$ & 1.52 & & 34.51 & $* *$ \\
\hline Welfare Support & 102.09 & $* *$ & 16.79 & $* *$ & 123.77 & $* *$ \\
\hline Professional Occupation & 39.69 & * & 0.03 & & 39.37 & $* *$ \\
\hline Sales/Admin Occupation & 1.75 & & 1.45 & & 0.16 & \\
\hline Service, Operations, Farm, Armed Forces & 1.31 & & 0.09 & & 0.65 & \\
\hline No Occupation & 30.26 & $* *$ & 0.62 & & 22.40 & $* *$ \\
\hline Urban & 1.68 & & 3.26 & + & 3.05 & + \\
\hline Northeast & 1.63 & & 0.41 & & 11.76 & $* *$ \\
\hline North Central & 0.03 & & 2.20 & & 1.08 & \\
\hline West & 1.20 & & 0.21 & & 3.50 & + \\
\hline South & 4.38 & * & 0.13 & & 0.15 & \\
\hline
\end{tabular}

Note. NLSY79 data limited to those age 22 and over with at least a four-year college degree.

those with and without student loans. This difference is not significant, however, for income. To assess variation in time to reach median wealth or income by other factors, Table 4 provides the chi square statistic and its significance for log 
rank tests of several variables, in addition to student loan holding. Results indicate significant differences in intragenerational mobility patterns by race, marital status, occupation category, and welfare support. Differences by region are not consistently significant.

\subsection{Net Worth}

Table 5 shows results using IHS transformed student loans to predict time to median wealth. As stated, descriptive analyses reveal that the average college student in this study acquires $\$ 24,534.42$ of student loan debt. In this study, even one third of the average amount, an additional $\$ 10,000$ in student loans, is associated with a $26 \%$ decrease in the rate of achieving median net worth (1 $\left.\exp \left(-0.03^{*} 9.9\right)\right)$.

Model 3 includes several additional covariates, including baseline net worth, postgraduate degree, family size, marital status, welfare support, occupational category, and geography. In this model, tests of Schoenfeld residuals showed that the proportional hazards assumption for baseline net worth, race, married, and occupational category did not hold $(p<0.10)$. We therefore include time-varying measures for these covariates to allow their relationship with likelihood of achieving median net worth to vary over time. With all of these measures included, the relationship between student loans and time to median wealth is still negative. Specifically, based on Model 3, an additional $\$ 10,000$ in student loans is associated with an $18 \%$ decrease in the rate of achieving median net worth, holding all else constant.

The relationship between student loans and time to reach median net worth could be simply mathematical. That is, those who have student loans could have lower net worth because of the amount of their outstanding student loan debt. In 2004 and 2008, NLSY79 collected the amount of outstanding student loan debt of the individual and his/her partner. Because this information is available in only two years, our main analyses include total net worth unadjusted for student loans. However, sensitivity analyses using an alternative measure of net worth that adds the total amount of outstanding student loans to 2004 and 2008 net worth measures yields similar results. That is, even when adjusting net worth for outstanding student loan debt, the negative relationship between student loans ever acquired and time to reach median net worth still holds. This result is far from conclusive but suggests that the delay in reaching median net worth is not simply due to the amount of student debt owed. Even when excluding student debt amounts from the calculation of net worth, those with student loans still reach the median more slowly.

\subsection{Income}

Table 6 presents results similar to those in Table 4, but for models predicting the time it takes an individual's total household income to reach median national household income. In all three models, the relationship between student loans 
Table 5. Cox proportion hazards models predicting time to median net worth.

\begin{tabular}{|c|c|c|c|c|}
\hline \multirow[b]{2}{*}{ Variable } & (1) & (2) & (3) & \multirow{2}{*}{$\begin{array}{c}(3) \\
\text { Time-Varying } \\
\text { Covariates }\end{array}$} \\
\hline & \multicolumn{3}{|c|}{ Time to Median Wealth } & \\
\hline \multirow[t]{2}{*}{ IHS Student Loans } & $-0.03^{* *}$ & $-0.03^{* *}$ & $-0.02^{* *}$ & \\
\hline & $(0.00)$ & $(0.00)$ & $(0.00)$ & \\
\hline \multirow[t]{2}{*}{ Male } & & $0.12^{* *}$ & $0.10^{*}$ & \\
\hline & & $(0.04)$ & $(0.04)$ & \\
\hline \multirow[t]{2}{*}{ Black } & & $-0.48^{* *}$ & $-0.35^{\star}$ & $0.13+$ \\
\hline & & $(0.05)$ & $(0.14)$ & $(0.07)$ \\
\hline \multirow[t]{2}{*}{ Latino } & & $-0.16^{* *}$ & $-0.27+$ & 0.09 \\
\hline & & $(0.06)$ & $(0.16)$ & $(0.09)$ \\
\hline \multirow[t]{2}{*}{ IHS Baseline Net Worth } & & & 0.04 & $0.24^{* *}$ \\
\hline & & & $(0.03)$ & $(0.02)$ \\
\hline \multirow[t]{2}{*}{ Postgraduate Degree } & & & $-0.13^{*}$ & \\
\hline & & & $(0.05)$ & \\
\hline \multirow[t]{2}{*}{ Family Size } & & & $-0.07^{\star *}$ & \\
\hline & & & $(0.02)$ & \\
\hline \multirow[t]{2}{*}{ Single } & & & 0.07 & \\
\hline & & & $(0.10)$ & \\
\hline \multirow[t]{2}{*}{ Married } & & & $1.14^{* *}$ & $-0.15^{*}$ \\
\hline & & & $(0.14)$ & $(0.06)$ \\
\hline \multirow[t]{2}{*}{ Welfare Support } & & & $-0.85^{\star *}$ & \\
\hline & & & $(0.18)$ & \\
\hline \multirow[t]{2}{*}{ Professional Occup } & & & $-2.76^{\star *}$ & $1.30^{* *}$ \\
\hline & & & $(0.84)$ & $(0.35)$ \\
\hline \multirow[t]{2}{*}{ Sales/Admin Occup } & & & $-3.92^{\star *}$ & $1.69^{* *}$ \\
\hline & & & $(1.10)$ & $(0.43)$ \\
\hline \multirow[t]{2}{*}{ Serv/Oper/Farm/Military } & & & $-4.03^{\star *}$ & $1.68^{* *}$ \\
\hline & & & $(1.15)$ & $(0.45)$ \\
\hline \multirow[t]{2}{*}{ Urban } & & & -0.04 & \\
\hline & & & $(0.06)$ & \\
\hline \multirow[t]{2}{*}{ North East } & & & 0.00 & \\
\hline & & & $(0.06)$ & \\
\hline \multirow[t]{2}{*}{ North Central } & & & 0.01 & \\
\hline & & & $(0.06)$ & \\
\hline \multirow[t]{2}{*}{ West } & & & $-0.11+$ & \\
\hline & & & $(0.06)$ & \\
\hline Observations & 20,312 & 20,312 & 19,179 & 19,179 \\
\hline
\end{tabular}

Note. NLSY79 data limited to those age 22 and over with at least a four-year college degree. The time-varying covariates are included in Model 3 only. Standard errors are in parentheses. ${ }^{*} p<0.01,{ }^{*} p<$ $0.05,+p<0.1$. 
Table 6. Cox proportion hazards models predicting time to median income: total income.

\begin{tabular}{|c|c|c|c|c|}
\hline \multirow[b]{2}{*}{ Variable } & (1) & (2) & (3) & \multirow{2}{*}{$\begin{array}{c}(3) \\
\text { Time-Varying } \\
\text { Covariates }\end{array}$} \\
\hline & \multicolumn{3}{|c|}{ Time to Median Income } & \\
\hline \multirow[t]{2}{*}{ IHS Student Loans } & -0.01 & -0.00 & -0.01 & \\
\hline & $(0.01)$ & $(0.01)$ & $(0.01)$ & \\
\hline \multirow[t]{2}{*}{ Male } & & 0.14 & 0.01 & \\
\hline & & $(0.12)$ & $(0.13)$ & \\
\hline \multirow[t]{2}{*}{ Black } & & $-0.41^{\star *}$ & $-0.52^{*}$ & 0.29 \\
\hline & & $(0.15)$ & $(0.24)$ & $(0.21)$ \\
\hline \multirow[t]{2}{*}{ Latino } & & $-0.35+$ & -0.37 & \\
\hline & & $(0.21)$ & $(0.24)$ & \\
\hline \multirow[t]{2}{*}{ IHS Baseline Total Income } & & & -0.01 & \\
\hline & & & $(0.01)$ & \\
\hline \multirow[t]{2}{*}{ Postgraduate Degree } & & & -0.07 & \\
\hline & & & $(0.15)$ & \\
\hline \multirow[t]{2}{*}{ Family Size } & & & 0.02 & \\
\hline & & & $(0.04)$ & \\
\hline \multirow[t]{2}{*}{ Single } & & & 0.05 & 0.01 \\
\hline & & & $(0.39)$ & $(0.20)$ \\
\hline \multirow[t]{2}{*}{ Married } & & & 0.28 & \\
\hline & & & $(0.36)$ & \\
\hline \multirow[t]{2}{*}{ Welfare Support } & & & $-1.06^{* *}$ & \\
\hline & & & $(0.37)$ & \\
\hline \multirow[t]{2}{*}{ Professional Occup } & & & 0.25 & \\
\hline & & & $(0.50)$ & \\
\hline \multirow[t]{2}{*}{ Sales/Admin Occup } & & & -0.64 & \\
\hline & & & $(1.01)$ & \\
\hline \multirow[t]{2}{*}{ Serv/Oper/Farm/Military } & & & -0.45 & 0.57 \\
\hline & & & $(0.75)$ & $(0.44)$ \\
\hline \multirow[t]{2}{*}{ Urban } & & & 0.25 & \\
\hline & & & $(0.19)$ & \\
\hline \multirow[t]{2}{*}{ North East } & & & 0.07 & \\
\hline & & & $(0.16)$ & \\
\hline \multirow[t]{2}{*}{ North Central } & & & -0.11 & \\
\hline & & & $(0.18)$ & \\
\hline \multirow[t]{2}{*}{ West } & & & 0.04 & \\
\hline & & & $(0.19)$ & \\
\hline Observations & 870 & 870 & 752 & 752 \\
\hline
\end{tabular}

Note. NLSY79 data limited to those age 22 and over with at least a four-year college degree. The time-varying covariates are included in Model 3 only. Standard errors are in parentheses. ${ }^{* *} p<0.01,{ }^{*} p<$ $0.05,+p<0.1$. 
and time to median income is small and negative, but not significantly different from zero.

Table 7 shows results similar to those in Table 5, but using household wage income rather than total income. In the first two models, the relationship between student loans and time to median income is not significantly different from zero. In Model 3, which controls for baseline wage income, postgraduate degree, family size, marital status, welfare support, occupational category, and geography, the relationship between student loans and time to median income is small but negative $(-0.01, p<0.05)$. In this model, tests of Schoenfeld residuals showed that the proportional hazards assumption for baseline wage income, gender, race, postgraduate degree, family size, and occupational category did not hold $(p<0.10)$. We include time-varying measures for these covariates to allow their relationship with likelihood of achieving median income to vary over time. Based on the coefficient for IHS student loans in Model 3, an additional \$10,000 in student loans is associated with a $9 \%$ decrease in the rate of achieving median income, holding all else constant.

\subsection{Variation by Race or Gender}

The slower achievement of median wealth among student loan holders could reflect race or other differences. For example, Black or Latino students who complete a college degree may be more likely to acquire student loans because their parents may be less able to pay for college and may acquire wealth more slowly for a variety of reasons. To address the possibility that race or some other factor is driving the relationship between student loans and intragenerational mobility, we use Cox proportional hazards models. To investigate whether the relationship between student loans and the timing of intragenerational mobility differs by race or gender, we first include interaction terms in Model 2 of each analysis above. Specifically, we interact IHS student loans with Black, Latino, and male. When we include these interaction terms one at a time in Model 2, which controls for gender and race, we find that only one is significant: IHS student loans $\mathrm{x}$ Black when predicting time to median net worth.

Giventhe largely null interaction effects, we present results from models limited to Black, Latino, other race, male, and female young adults. Table 8 shows the estimated relationship between student loans and time to median net worth or income for each group. In each case, the model estimates the relationship between IHS student loans and time to median net worth or income, including no other covariates. As in Table 6 and Table 7, there is no significant relationship when predicting time to median income. For median net worth, the results suggest a slight negative relationship between student loans and the rate of achieving median net worth for all groups except Blacks.

The negative relationship between student loans and time to reach median net worth for all others groups suggests that student loans may hinder the ability of young adults to build wealth and achieve upward mobility. The nonsignificant coefficient for Blacks suggests that student loans may not present an additional 
Table 7. Cox proportion hazards models predicting time to median income: wage income.

\begin{tabular}{|c|c|c|c|c|}
\hline \multirow[b]{2}{*}{ Variable } & (1) & (2) & (3) & \multirow{2}{*}{$\begin{array}{c}\text { (3) } \\
\text { Time-Varying } \\
\text { Covariates }\end{array}$} \\
\hline & \multicolumn{3}{|c|}{ Time to Median Income } & \\
\hline \multirow[t]{2}{*}{ IHS Student Loans } & -0.00 & -0.00 & $-0.01^{\star}$ & \\
\hline & $(0.00)$ & $(0.00)$ & $(0.00)$ & \\
\hline \multirow[t]{2}{*}{ Male } & & 0.01 & -0.02 & $0.10+$ \\
\hline & & $(0.05)$ & $(0.07)$ & $(0.06)$ \\
\hline \multirow[t]{2}{*}{ Black } & & $-0.45^{* *}$ & $-0.28^{* *}$ & $0.13+$ \\
\hline & & $(0.06)$ & $(0.10)$ & $(0.07)$ \\
\hline \multirow[t]{2}{*}{ Latino } & & $-0.28^{* *}$ & $-0.14+$ & \\
\hline & & $(0.07)$ & $(0.08)$ & \\
\hline \multirow[t]{2}{*}{ IHS Baseline Wage Income } & & & $0.07^{\star *}$ & $-0.03^{* *}$ \\
\hline & & & $(0.01)$ & $(0.01)$ \\
\hline \multirow[t]{2}{*}{ Postgraduate Degree } & & & $-0.30^{\star *}$ & $0.30^{\star *}$ \\
\hline & & & $(0.09)$ & $(0.08)$ \\
\hline \multirow[t]{2}{*}{ Family Size } & & & $-0.12^{* *}$ & $0.05^{*}$ \\
\hline & & & $(0.03)$ & $(0.02)$ \\
\hline \multirow[t]{2}{*}{ Single } & & & 0.20 & \\
\hline & & & $(0.15)$ & \\
\hline \multirow[t]{2}{*}{ Married } & & & $1.17^{\star \star}$ & \\
\hline & & & $(0.16)$ & \\
\hline \multirow[t]{2}{*}{ Welfare Support } & & & $-1.88^{\star *}$ & \\
\hline & & & $(0.25)$ & \\
\hline \multirow[t]{2}{*}{ Professional Occup } & & & -0.71 & $0.78^{\star *}$ \\
\hline & & & $(0.64)$ & $(0.27)$ \\
\hline \multirow[t]{2}{*}{ Sales/Admin Occup } & & & -0.70 & $0.55+$ \\
\hline & & & $(0.66)$ & $(0.28)$ \\
\hline \multirow[t]{2}{*}{ Serv/Oper/Farm/Military } & & & -0.65 & $0.60^{\star}$ \\
\hline & & & $(0.53)$ & $(0.23)$ \\
\hline \multirow[t]{2}{*}{ Urban } & & & $0.20^{* *}$ & \\
\hline & & & $(0.07)$ & \\
\hline \multirow[t]{2}{*}{ North East } & & & $0.25^{\star *}$ & \\
\hline & & & $(0.06)$ & \\
\hline \multirow[t]{2}{*}{ North Central } & & & -0.04 & \\
\hline & & & $(0.06)$ & \\
\hline \multirow[t]{2}{*}{ West } & & & -0.07 & \\
\hline & & & $(0.07)$ & \\
\hline Observations & 9319 & 9319 & 7904 & 7904 \\
\hline
\end{tabular}

Note. NLSY79 data limited to those age 22 and over with at least a four-year college degree. The time-varying covariates are included in Model 3 only. Standard errors are in parentheses. ${ }^{*} p<0.01,{ }^{*} p<$ $0.05,+p<0.1$. 
Table 8. IHS student loan coefficients in samples limited by race and gender.

\begin{tabular}{cccccccc}
\hline Sample & $\begin{array}{c}\text { Median Net } \\
\text { Worth }\end{array}$ & & $N$ & $\begin{array}{c}\text { Median } \\
\text { Total } \\
\text { Income }\end{array}$ & $N$ & $\begin{array}{c}\text { Median } \\
\text { Wage } \\
\text { Income }\end{array}$ & $N$ \\
\hline Black & -0.01 & & 5525 & 0.01 & 268 & 0.01 & 2887 \\
Latino & -0.04 & $* *$ & 2680 & -0.05 & 118 & 0.00 & 1262 \\
Other Race & -0.03 & $* *$ & 12107 & 0.00 & 484 & -0.01 & 5170 \\
Male & -0.02 & $* *$ & 8521 & -0.03 & 310 & 0.00 & 4327 \\
Female & -0.03 & $* *$ & 11791 & 0.00 & 560 & -0.01 & 4992 \\
All & -0.03 & $* *$ & 20312 & -0.01 & 870 & 0.00 & 9319 \\
\hline
\end{tabular}

Note. NLSY79 data limited to those age 22 and over with at least a four-year college degree. All models are Cox proportional hazards models, include only IHS student loans, and are limited to the race or gender group in the sample column. ${ }^{* *} p<0.01,{ }^{*} p<0.05,+p<0.1$.

hurdle to net worth accumulation for Black young adults. This could reflect high rates of student borrowing by Blacks (i.e., a small number in the comparison group without loans in the Black sample), the difficulty of achieving median net worth for Black households with or without loans, or some other factor. Further research on the relationship between student loans and intragenerational mobility within racial groups is warranted.

\section{Discussion}

In America, education is a key tool for providing equal opportunity. Early on, policymakers realized that it is not enough to have a public education system. For education to function as a catalyst of equitable economic mobility, it also must be accessible to everyone. As higher educational attainment became increasingly essential to individuals' financial security and upward mobility, access to postsecondary institutions emerged as a major policy challenge. In an attempt to make colleges and universities accessible to all, the federal government began providing financial aid, a commitment always tempered by ideology that largely frames higher education as a "private" good. In recent years, the value of need-based financial aid-once the cornerstone of the nation's investment in college access-has eroded in the face of rising tuition costs. Student loan usage has skyrocketed in this breach, despite little evidence to support reliance on student borrowing as a complement to education's equity aims. Concerns about student loan debt have led to research which underscores that how students pay for college matters. This study builds on this emerging scholarship by examining the relationship between student debt and the time it takes to move up the economic ladder to the midpoint of the income and asset distributions, a measure that can be understood as having "made it" in the U.S. economy.

\subsection{Delayed Returns on a Degree: The Case of Net Worth}

Findings from this study reveal that college graduates with outstanding student debt take longer to move up the economic ladder and reach the midpoint of the 
net worth distribution than college graduates without outstanding student debt. Specifically, an additional $\$ 10,000$ of student debt, only one third of the average amount college students acquire (Miller, 2014), is associated with a $26 \%$ decrease in the rate of achieving median net worth. Even after controlling for key variables such as baseline net worth, postgraduate degree, family size, marital status, welfare support, occupational category, and geography, acquiring \$10,000 in student loans is still associated with a $16 \%$ decrease in the rate of achieving median net worth. These findings are consistent with past research which finds that being a college graduate with student loans is associated with having less net worth (e.g., Cooper \& Wang, 2014; Elliott \& Nam, 2013; Fry, 2014, Hiltonsmith, 2013).

While today problematic student debt is often characterized as $\$ 100,000$ or more per borrower, findings from this study suggest that much smaller amounts of student loans may be associated with reduced return on a college degree. These findings are consistent with other research that indicates that small amounts of debt may be associated with poor financial outcomes for graduates with outstanding student debt (e.g., Brown et al., 2014; Elliott \& Nam, 2013; Zhan, Xiang, \& Elliott, 2016). For example, Zhan et al. (2016) found that having outstanding student loans was statistically associated with having less net worth when compared to not having outstanding student loans, but amount of student debt did not have a statistically significant relationship with net worth. Brown et al. (2014) found that the highest default rates, at nearly $34 \%$, are among borrowers who owe less than $\$ 5,000$. Moreover, Akers (2014) found that "high-debt borrowers face financial hardship at only slightly higher rates than comparable households with less debt" (p. 4).

In our study, when Black college graduates with outstanding student debt are compared to other Black college graduates, we find no statistical difference in net worth. The null relationship among Blacks could represent the difficulty faced by this group in building net worth, regardless of student loan debt (Conley, 1999; Shapiro, 2004). For example, if Blacks face additional challenges or discrimination in the mortgage market, they may be less able to build their net worth regardless of student debt. Alternatively, the null relationship could suggest that Black college graduates who have outstanding student debt may receive the same return on a degree as Black college graduates who do not have student loans, although this does not mean they enjoy the same return on a degree as other racial/ethnic groups (Emmons \& Noeth, 2015). Zhan et al.'s (2016) finding that Black college-goers without outstanding student loans reported significantly less net worth than White college-goers without outstanding student loans may support this contention. However, these findings warrant further research to better understand how and why the relationship between student loans and net worth differs by race.

\subsection{Delayed Returns on a Degree: The Case of Income}

This study finds some evidence that college graduates who have outstanding 
student debt take longer to reach median income when compared to college graduates who do not have outstanding debt. An additional \$10,000 in student loans is associated with a $9 \%$ decrease in the rate of achieving median income. However, graphical evidence suggests that differences do not emerge until about age 35. Similarly, Hiltonsmith (2013) found that college graduates with outstanding student debt start off earning more than their counterparts without outstanding student debt, but by their early 40 s college graduates without outstanding student debt begin to earn more, a difference that becomes statistically significant by their mid-50s. This dynamic may be due to career choices. Previous research shows that college graduates with outstanding student debt opt for higher-paying jobs upon graduation, even within the same profession, due to anxiety about paying back their student loans (e.g., Minicozzi, 2005; Rothstein \& Rouse, 2011).

This fast earnings start may be counterbalanced by a slow asset start by college graduates with outstanding student debt. This brings up an interesting question for research on lifetime earnings of college graduates. Such research has been constructed with the question in mind, "Is a young adult who graduates from college better off than if he/she did not graduate from college?" As such, the comparison is between college graduates and those without college degrees. However, our findings and Hiltonsmith's (2013) findings suggest that over the course of a college graduate's lifetime, those with outstanding student debt may acquire fewer assets than their counterparts without outstanding student loan debt. There is some evidence to suggest that this might be because college graduates with outstanding student debt delay investing in income-building assets (e.g., Egoian, 2013; Houl \& Berger, 2014). Because of compound interest and other cumulative benefits of early wealth accumulation, even small delays can generate substantial inequality later in life. These delays in achieving asset-building milestones in route to achieving the American Dream result in college graduates with outstanding student debt falling behind and may, then, contribute to the persistent wealth inequality observed in the U.S. today (see Piketty, 2014).

\subsection{Policy Implications}

The findings from this study reveal that college graduates who have to pay for college with student loans take longer to reach median net worth than their counterparts who do not have student loans. This indicates there is a real price for paying for college with student loans, not just for the individual but for society. The economy relies on people buying homes and investing in their own retirement, and these activities may be constrained among student borrowers. There is also a social price to pay. Given that education is believed by many to be one of the key mechanisms for creating equality in society, if college graduates see others benefit more from their degrees without apparently working harder, they may begin to question the calculus of education as an equalizer and, indeed, the general fairness of society. Moreover, because low-income students and mi- 
norities disproportionately rely on student loans to pay for college (Huelsman, 2015), policies that promote student loan use as a way to finance college introduce or exacerbate inequality in the higher education system. It is not enough that students have a way to pay for college. Our results add to a growing body of evidence that suggests that how they pay for college also matters. If a key role of education is to create greater economic mobility and equity, we suggest that financial aid policies should augment, not undermine, education's capacity to function as an equalizer. As asset-based approaches to financial aid, Children's Savings Accounts (CSAs) may be one such intervention. Typically started at birth or kindergarten, CSAs leverage families' investments with an initial deposit and matching donor funds, usually at a 1:1 ratio. Unlike student debt, CSAs have the potential to work on multiple dimensions-early education, affordability, completion, and post-college financial health-to improve outcomes and catalyze opportunity (Elliott \& Lewis, 2015).

Findings also bring into question current student loan repayment policies such as Income-Based Repayment and even deferment and forbearance. By extending the time it takes to pay off student loans, these programs help treat the symptom-student loan default-but may worsen the student loan crisis in the long run. This is because they delay asset building by prolonging repayment. Additionally, because low-income and minority students disproportionately rely on student loans as a way to pay for college, such policies may exacerbate U.S. racial wealth inequality.

Another implication is that, contrary to the focus on high-dollar debt, even relatively small amounts of debt can be associated with failing to move up the economic ladder to the midpoint of the distribution. The uncertainty about how much debt is too much debt brings into question current practice of making student loans the primary tool for facilitating access to higher education. Indeed, our results suggest that any student loan debt is too much. Access, in other words, should not be considered without also thinking about equity.

\section{Conclusion}

Some may view these student loan effects as small costs to pay for the right to receive an education. Indeed, some Americans may choose to delay buying a home or saving for retirement for reasons unrelated to student debt, and generational differences may lead some to make different life choices altogether. Our intention here is to point out the unacceptable inequity of a system that asks some, but not all, students to pay these costs, and that frames such inequity as an inevitable price of higher education access. We posit that the American Dream requires that personal preferences and life goals must determine individuals' paths, not constraints leveled by the way in which they financed the higher education they pursued on their journey. This leads to different conclusions about the seriousness of student loan effects and, then, the urgency of constructing alternatives. 


\section{References}

Akers, B. (2014). How Much Is Too Much? Evidence on Financial Well-Being and Student Loan Debt. Washington DC: American Enterprise Institute.

Akers, B., \& Chingos, M. M. (2014). Is a Student Loan Crisis on the Horizon? Washington DC: Brookings Institution.

American Student Assistance (2013). Life Delayed: The Impact of Student Debt on the Daily Lives of Young Americans. Washington DC: American Student Assistance.

Brown, M., \& Caldwell, S. (2013). Young Adult Student Loan Borrowers Retreat from Housing and Auto Markets. New York, NY: Federal Reserve Bank of New York.

Brown, M., Haughwout, A., Lee, D., Scally, J., \& van der Klaauw, W. (2014). Measuring Student Debt and Its Performance (No. 668). Staff Reports, New York, NY: Federal Reserve Bank of New York.

Carnevale, A. P., \& Strohl, J. (2010). How Increasing College Access Is Increasing Inequality, and What to Do about It. In R. Kahlenberg (Ed.), Rewarding Strivers: Helping Low-Income Students Succeed in College (pp. 1-231). New York, NY: Century Foundation Books.

Cooper, D., \& Wang, C. (2014). Student Loan Debt and Economic Outcomes. Current Policy Perspectives, Boston: Federal Reserve Bank of Boston.

https://www.bostonfed.org/publications/current-policy-perspectives/2014/student-loan -debt-and-economic-outcomes.aspx

Conley, D. (1999). Being Black, Living in the Red. Berkeley, CA: University of California Press.

Dynarski, S. M. (2016). The Dividing Line between Haves and Have-Nots in Home Ownership: Education, Not Student Debt. Brookings, 1, 1-4.

Egoian, J. (2013). 73 Will Be the Retirement Norm for Millennials. http://www.nerdwallet.com/blog/investing/2013/73-retirement-norm-millennials/

Elliott, W., Grinstein-Weiss, M., \& Nam, I. (2013). Student Debt and Declining Retirement Savings. St. Louis, MO: Washington University, Center for Social Development.

Elliott, W., \& Lewis, M. (2017). Student Debt: A Reference Handbook. Santa Barbara, CA: ABC-CLIO.

Elliott, W., \& Lewis, M. (2015). The Real College Debt Crisis: How Student Borrowing Threatens Financial Well-Being and Erodes the American Dream. Broomfield, CO: Praeger.

Elliott, W., \& Nam, I. (2013). Is Student Debt Jeopardizing the Long-Term Financial Health of U.S. Households? St. Louis, MO: St. Louis Federal Reserve Bank. http://citeseerx.ist.psu.edu/viewdoc/download?doi=10.1.1.401.2486\&rep=rep1\&type $=$ p df

Emmons, W. R., \& Noeth, B. J. (2015). Why Didn't Higher Education Protect Hispanic and Black Wealth? St. Louis, MO: St. Louis Federal Reserve Bank. https://www.stlouisfed.org/ /media/Publications/In-the-Balance/Images/Issue_12/ITB August_2015.pdf

Fry, R. (2014). Young Adults, Student Debt and Economic Well-Being. Washington DC: Pew Research Center's Social and Demographic Trends Project.

Greenstone, M., Looney, A., Patashni, J., \& Yu, M. (2013). Thirteen Economic Facts about Social Mobility and the Role of Education. Washington DC: Brookings Institution.

Grinstein-Weiss, M., Perantie, D. C., Taylor, S. H., Guo, S., \& Raghavan, R. (2016). Racial Disparities in Education Debt Burden among Low- and Moderate-Income Households. 
Children and Youth Services Review, 65, 166-174.

https://doi.org/10.1016/j.childyouth.2016.04.010

Hartman, R. R. (2013). Who Makes Money Off Your Student Loans? You Might Be Surprised. Yahoo News.

http://news.yahoo.com/blogs/the-lookout/makes-money-off-student-loans-might-surp rised-093332073.html

Hershbein, B. (2016). A College Degree Is Worth Less If You Are Raised Poor. http://www.brookings.edu/blogs/social-mobility-memos/posts/2016/02/19-college-degr ee-worth-less-raised-poor-hershbein

Hiltonsmith, R. (2013). At What Cost: How Student Debt Reduces Lifetime Wealth. New York, NY: Demos.

Houle, J., \& Berger, L. (2014). Is Student Loan Debt Discouraging Home Buying among Young Adults? Association for Public Policy and Management.

http://www.appam.org/assets/1/7/Is_Student_Loan_Debt_Discouraging_Home_Buyin g_Among_Young_Adults.pdf

Huelsman, M. (2015). The Debt Divide: The Racial and Class Bias Behind the "New Normal" of Student Borrowing. Washington DC: Demos.

Janowitz, M. (1976). Social Control of the Welfare State. New York, NY: Elsevier Scientific Publishing Co.

Miller, B. (2014). The Student Debt Review Analyzing the State of Undergraduate Student Borrowing. Washington DC: New America.

Minicozzi, A. (2005). The Short Term Effect of Educational Debt on Job Decisions. Economics of Education Review, 24, 417-430. https://doi.org/10.1016/j.econedurev.2004.05.008

Mishory, J., \& O'Sullivan, R. (2012). Denied? The Impact of Student Debt on the Ability to Buy a House. Washington DC: Young Invincibles.

Piketty, T. (2014). Capital in the Twenty-First Century. Translated by Arthur Goldhammer. Boston, MA: Belknap Press. https://doi.org/10.4159/9780674369542

Rose, S. (2014). The Value of a College Degree. Change: The Magazine of Higher Learning, 45, 24-33. https://doi.org/10.1080/00091383.2013.842101

Rothstein, J., \& Rouse, C. E. (2011). Constrained after College: Student Loans and Early-Career Occupational Choices. Journal of Public Economics, 95, 149-163. https://doi.org/10.1016/j.jpubeco.2010.09.015

Saez, E., \& Zucman, G. (2016). Wealth Inequality in the United States since 1913: Evidence from Capitalized Income Tax Data. The Quarterly Journal of Economics, 131, 519-578. https://doi.org/10.1093/qje/qjw004

Shand, J. M. (2007). The Impact of Early-Life Debt on the Homeownership Rates of Young Households: An Empirical Investigation. Federal Deposit Insurance Corporation Center for Financial Research.

http://citeseerx.ist.psu.edu/viewdoc/download?doi=10.1.1.527.6788\&rep=rep1\&type $=$ p df

Shapiro, T. M. (2004). The Hidden Cost of Being African American: How Wealth Perpetuates Inequalities. New York, NY: Oxford University Press.

Shapiro, T., Meschede, T., \& Osoro, S. (2013). The Roots of the Widening Racial Wealth Gap: Explaining the Black-White Economic Divide. Waltham, MA: Brandeis University, Institute on Assets and Social Policy.

Stone, C., Van Horn, C., \& Zukin, C. (2012). Chasing the American Dream: Recent Col- 
lege Graduates and the Great Recession. New Brunswick, NJ: Center for Workforce Development. https://files.eric.ed.gov/fulltext/ED535270.pdf

Zhan, M., Xiang, X., \& Elliott, W. (2016). Education Loans and Wealth Building among Young Adults. Children and Youth Services Review, 66, 67-75.

https://doi.org/10.1016/j.childyouth.2016.04.024 